\title{
The influence of foreign patterns in the morphology section of Ioan Piuariu-Molnar's grammar (Deutsch-Walachische Sprachlebre, Vienna, 1788)
}

\author{
Ana-Maria Minuț, Ion Lihaciu* \\ Faculty of Letters, "Alexandru Ioan Cuza" University, Bd. Carol I 11, 700506 Iaşi, Romania
}

\begin{abstract}
Article info
History:

Key words:

diachrony

linguistic contact

historical grammar
\end{abstract}

Received January 14, 2018

Accepted February 18, 2018

Published April 27, 2018

\begin{abstract}
One of the stages we have made in the process of publishing the German-Romanian grammar of Ioan Piuariu Molnar consisted in identifying the patterns followed by the author. The statement which claims that Molnar's grammar followed the pattern of Samuel Micu and George S,incai's grammar, Elementa lingue daco-romane sive valachice (Vienna, 1780) is widespread in today's literature review. We have found that, in case of some grammar chapters, the influence of this model is clearly confirmed. But there are also chapters different from their corresponding ones in Elementa or chapters that emerge only in Molnar's grammar, not in that one of Micu and Sincai. This is explained by the fact that Molnar also followed the pattern of foreign grammars, which at that time were successful and were widely spread; these are two French grammars written in German with Latin grammatical terminology: the work of J.R. des Pepliers, Nouvelle et parfaite grammaire royale françoise et allemande. Neue und vollständige königliche französische Grammatik, bisher unter dem Nahmen des Herrn der Pepliers vielmals herausgegeben (Leipzig, 1765, M. G. Weidmanns Erben und Reich Printing House), respectively the grammar of Hilmar Curas, Erleichterte und durch lange Erfahrung verbesserte französische Grammatik (Berlin, 1759, Friedrich Nicolai Printing House). In this article we have revealed the chapters of morphology in which the influence of the Pepliers and Curas' grammars is confirmed. The influence of foreign patterns is reflected in: the structure of the chapters, the used terminology and the German sequence of words; on the latter, we have highlighted where German equivalents for the Romanian words indicated by Molnar are identical with the German equivalents listed in Pepliers' grammar or that of Curas for the French words.
\end{abstract}

\section{Preamble}

Famous among contemporaries thanks, first and foremost, to his outstanding career as eye doctor of the “The Great Principality of Transylvania”, Ioan Piuariu Molnar (1749, Sadu [Sibiu County] - 1815, Sibiu) is also part of the series of the Transylvanian intellectuals involved, starting in the second half of the $18^{\text {th }}$ century during the modernization of the Romanian society, according to the western style. The "pragmatic attitude" (Niculescu, 1978, p. 59) of the Transylvanian scholars, fully adapted to the political, social, and cultural realities of time, materializes, on the one hand, in writing grammars and dictionaries, which had the role of changing the literary Romanian into a perfect means of communication, phonetically and grammatically by a corresponding lexicon; on the other hand, the Transylvanian Illuminati have the fundamental merit of initiating organized dissemination actions, through their theoretical and practical works, translations and originals (from history, philosophy, rhetoric, theology, mathematics, natural sciences, medicine, geography, physics, chemistry, agronomy), the Western science and culture.

\footnotetext{
*Email addresses:a_minut@hotmail.com(AMM),lihaciu@uaic.ro (IL).
} 
Ana-Maria Minuț, Ion Lihaciu

Ioan Piuariu-Molnar is part of the same limited belief, who as an "agent" (according to Pierre Bourdieu's doctrine) of several socially determined "fields" stood out both as an author of a German-speaking grammar (Deutsch-Walachische Sprachlehre, Vienna, 1788; Sibiu, 1810; Sibiu, 1823), as well as of a German dictionary (Wörterbüchlein deutsch und wallachisches, Sibiu, 1822) and the first book of rural economics (Economia stupilor, Vienna, 1785; Sibiu, 1808), as editor ${ }^{1}$ of a rhetoric (Retorică, adecă învățătura și întocmirea frumoasei cuvîntări. Acum întăi izvodită pe limba românească. Impodobită și întemeiată cu pildele vechilor filosofi și dascali bisericești, Buda, 1798) and as a translator ${ }^{2}$ of Istoria universală, adecă de obște, care cuprinde în sine întîmplările veacurilor vechi, întocmită prin Signior Milot, commembrum Academiei Frîncești din Lion (Buda, 1800).

\section{Deutsch-Walachische Sprachlehre}

\subsection{Objectives}

Deutsch-Walachische Sprachlehre is not, as it might be understood from the title, a German-Romanian comparative grammar, but a grammar of the Romanian written language in German; the grammatical theory strictly refers to Romanian, and all Romanian examples have a German equivalent. By this work, Molnar achieves at least three important objectives: the first is to consider the Romanian language (by setting numerous, clear, concise and richly illustrating rules); the second is about providing a Romanian Handbook to the Austrian officials who worked in Transylvania and to foreign merchants. Thirdly, by introducing chapters in which Romanian statements used in various communication situations (At the table, At the tailor, About housing, writing, shopping, disputes and legal actions which represent a social threaten, war, travel, human specific attitudes, the symptoms of disease, etc.), samples of application forms (for getting a job "to canțelarie" for exemption of barracks obligations etc.) and letters of (recommendation, condolences, congratulations, etc.) are offered, he is trying to bring Romanian at a level where the same content can semantically and stylistically express itself as a refined language like German.

\subsection{Versions}

Its three editions ${ }^{3}$ explain the success of the work. The first edition of 1788, is signed "Johann Molnar, royal eye doctor of The Principality of Transylvania"; as Molnar was appointed professor of ophthalmology in Cluj in 1791, later (in 1792) receiving the noble title of "von Müllersheim", in the edition of 1810 the title held by the author is revised as "Johann Molnar v. Müllersheim, royal eye doctor in The Great Principality of Transylvania and public eye professor at the University of Cluj." In the third posthumously published edition, the adjective fost [former] preceded the same title: "Johann Molnar v. Müllersheim, former royal eye doctor in The Great Principality of Transylvania and public professor of eye diseases at the University of Cluj." Known as Ioan Piuariu-Molnar, the author signs his work, as it can be seen, with the name of Molnar, the Hungarian equivalent of Piuariu, from the common noun piuariu "morar" [miller] (as Müller, from the noble title "von Müllersheim", is the German equivalent of the same word).

The 1788 edition was published in Vienna, at "Joseph Nobil von Kurzbek, the royal printer, high merchant and books seller" while the editions of 1810 and 1823 were printed in Sibiu, at "Martin Hochmeister, royal printer" printing house. In addition to his high state positions (magistrate, senator, mayor of Sibiu), Martin Hochmeister (junior) was a famous printer and librarian, member (since 1789) of the

\footnotetext{
${ }^{1}$ For further details on the idea that Molnar authored and translated the Retorica published in 1798, see Ursu (2002, p. 332-346), which states that Molnar is only the text editor of an older translation of Francesco Scuffi's Handbook, Arta retoricii, published in Venice in 1681 .

${ }^{2}$ Ursu (2002, p. 347-352) believes that Molnar also translated the popular book Viața lui Bertoldo și a lui Bertoldino, feciorul lui, dimpreună și a lui Cacasino, nepotul lui, published anonymously in Sibiu in 1799.

${ }^{3}$ For example, the edition of 1788 can be found at Österreichische Nationalbibliothek, in Vienna (book share: 38. H.21 [in print], MF 3195 [microfilm] or at http://data.onb.ac.at/rec/AC10132890 [digital]); the edition of 1810 is to be found at the Library of the Romanian Academy, Iași Branch, old books and manuscript collection, having the inventory number 000097; the edition of 1823 can be found at BCU Cluj-Napoca, Old Romanian Bibliography collection (1186 book share).
} 
same Masonic Lodge of Saint Andrew, of which Molnar was a member since 1781 (where he has been advanced to the rank of companion in 1783 and of master in 1784). It is likely that the posthumously publication of the third edition of Molnar's grammar to be owed to Hochmeister jr.

Compared to the first edition, some Romanian and especially German words (which had previously been misspelled) were corrected in the following ones (especially in the third one) or some German equivalents of Romanian words were replaced with other more appropriate ones. What makes the difference is the absence, in the third edition, of the acknowledgment section where Molnar expresses his gratitude to his benefactor, Georg Banffi von Losonz. Also, compared to the first two editions, the preface is considerably reduced in the next one, where the author is convinced about the usefulness of such grammars, while the "business needs" a language spoken extensively "in Transylvania, Bukovina, Banat and partly in Hungary."

\subsection{Structure}

Besides the preface, all three editions of the German-Romanian grammar include: a spelling section (divided into three chapters), a morphology section (with 19 chapters), a syntax section (four chapters), a Collection of Romanian and German words, Some dialogues, to talk about different states before, Some stories, and the chapter Stories, books, and other notes. Under these circumstances it might be said that the author approached grammar according to its current meaning (completely science of language), therefore, incorporating in his work other sections besides morphology and syntax. Therefore, we point that the structure of the work is justified by the preface: "Given the total lack of a dictionary, this grammar would not be very helpful if it somehow did not fill the role of a lexicon. Hence, annexes should be allowed which do not really have a place in a grammar, at least until a Romanian dictionary and handbook will be published." Defining his work as "an attempt of a notorious introduction whose main merit is the completeness and correctness of rules as well as its brief discourse", the author also clarifies the absence of a "deeper etymological research" that "rather seemed to find its place in a comprehensive scholarly grammar."

\subsection{Specific features}

At a simple grammar review two aspects instantly draw the attention. The first concerns the transcription of the Romanian words for the German reader. These are firstly written by using a Cyrillic alphabet and then transcribed by Latin letters according to the phonetic rules of the German spelling, the author hoping that "this kind of presentation of the Latin pronunciation can guide the Romanian-language lover."

The second aspect deals with the grammatical terminology; although the grammar is written in German, the used grammatical terminology is Latin. The Latin words being included in the German pronouncements are subject to the recitation rules of this language; when we translated the text, we saved the Latin terminology, observing however the Romanian conditions. For example, a title like: Von den Conjugationibus Verborum Regularium has the Romanian equivalent of Despreconjugatio nes verborum regularium (von being built up by the German dative, and despre by the Romanian accusative), Von dem Articulo definito des weiblichen Geschlechts has the Romanian equivalent Despre articulum definitum de genulfeminin; Von der Bildung des Nominativi Pluralis aus dem Nominativo Singularis has the Romanian equivalent of Despreformarea no minativi pluralis delanominativum singularem, etc.

\subsection{Model patterns}

The idea that Molnar closely followed the pattern of Samuil Micu and Gheorge Șincai's grammar, Elementa lingue daco-romane sive valachice (published in Vienna in 1780) is widespread in the literature review. We found that in case of some grammar chapters or sections, the influence of this pattern is clearly confirmed. But there are also chapters different from those in Elementa or chapters which occur only in Molnar's grammar, not in Micu and Șincai's. The explanation is that Molnar followed the pattern of some foreign grammars, which were highly successful and were widely spread. 
Studying more grammars of the $18^{\text {th }}$ century, we focused in particular on those designed (as well as Molnar's work) how to learn a foreign language; we thus examined grammars such as: French, Italian, Latin and Hungarian, all written in German (aiming at being learnt by the German readers). We noticed that these grammars share a common pattern, meaning that they share a similar structure: all include chapters of spelling, morphology, syntax, lexicon, and chapters that include dialogues, stories, and various patterns of statements. There are all sorts of analogies among chapters; in the vocabulary section, for example, the limits are always set onomasiologically (Despre Dumnezeu, Despre lume, Despre pămînt, Despre locuință, etc.), and thus the resulted fields share many features. Of all studied grammars we particularly paid attention to two because, beyond the clearly confirmed common pattern of Molnar's grammar other common aspects can be noticed as well. It's about two French grammars written in German but using a Latin grammar terminology (like Molnar's grammar): J.R. des Pepliers' work: Nouvelle et parfaite grammaire royale françoise et allemande. Neue und vollständige königliche französische Grammatik, bisher unter dem Nahmen des Herrn der Pepliers vielmals herausgegeben (we studied the Leipzig version of 1765 at MG Weidmanns Erben und Reich printing house), namely Hilmar Curas' grammar, Erleichterte und durch lange Erfahrung verbesserte französische Grammatik (we studied the version published in Berlin in 1759 by Friedrich Nicolai's Printing House).

Such grammars (published in highly numerous editions for that time and which have benefited from several successive edits) designed for German readers to learn a foreign language have undoubtedly been useful to Molnar for some reasons. A first reason concerns the German sequence of words; in our analysis, we reported those situations where the German equivalents cited by Molnar for the Romanian words are identical to the German equivalent quoted by Pepliers' grammar or that of Curas' for the French words. Another second reason refers to the structure of the chapters. Thirdly, being written in German and using a Latin grammatical terminology, such works provided Molnar with statements wording patterns. Comparing the original (German) text of Molnar's grammar with the German texts by Pepliers and Curas, comments or recommendations can be observed in identical or similar wordings.

We also surveyed the German grammar written in Latin by Georgius Nagy, Elementa lingue germanice (Vienna, 1775), which Ursu (2012, p. 27) offered as a pattern followed by Samuil Micu and Gheorge Sincai to compose Elementa lingua daco-romana sive valachica.

\section{The influence of foreign patters in the morphology section of Molnar's Grammar}

In the present study, we examined the way in which the influence of foreign patterns materialized in the morphology section of Molnar's grammar, titled Despre cercetarea cuvintelor (Etymologia). As commonly used, Molnar makes use of the word etimology with the meaning of 'morphology'. Originally, therefore, in German, the title is identical to Pepliers' grammar: Von der Wortforschung (De l'étymologie). In nine of the 19 chapters that make up the morphology section, the influence of foreign patterns is evident.

\subsection{Chapter on adjectives}

In Chapter IX, Despre comparatie (Comparatio), information is provided on the formation of the comparative of superiority (by help of the adverb mai [more]) and of the superlative (using the adverbs prea [too] and foarte [very]) from the positive degree. Inside this chapter, a Romanian "repertoire of the most common a d je ctiv or u m" is also included. Within this inventory, which contains over 500 words-title, apart from adjectives, we noticed some adverbs or adverbial phrases (vitejaşte, creștinește, omeneşte, cu direptul, cu grabă, intr-adins, geaba, etc.), in alphabetical order. If in Elementa there is not such a "repository" of adjectives, Pepliers' grammar contains a comprehensive Recueil des adjectifs les plus familiers \& les plus usités/Sammlung der gemeinsten und gebräuchlichsten A djectiv or um (with over 800 wordstitle), while Curas' grammar contains an Auszug der gebräuchlichsten Adjectivorum (with over 600 words-title). 


\subsection{Chapter on numerals}

Besides the cardinal and ordinal numerals, which are recorded in Elementa, Molnar states the following in his grammar: comparative (p ro portio na lia), distributive (distributiva), collective (collectiva). The same nomina numeralia can be found in Pepliers and Curas' grammar: cardinalia, ordinalia, proportionalia, collectiva, distributiva. In addition, in Curas' grammar, as well as in Molnar's, the cardinal numerals are also called Hauptzahlen (i.e., "fundamental" ${ }^{\prime}$ ).

Numeri proportionales, also called multiplicativi, are: de un feliu, îndoit, întreit, inpătrat, insutit, having the German equivalents einfach, zweifach, dreifach, vierfach, hundertfach. Exactly the same German examples are found in Curas, as equivalents of the following French numerals: simple, double, triple, quatruple, centuple. "As for the others", i.e. when there are not any forms created by the cardinal through a verb (în + doi > a îndoi > indoit etc.), Molnar's grammar indicated forms are: încăo datăpe atîta, noch einmal so viel; de șasă ori pe atîta, sechsmal so viel; de o sută de ori, hundertmal. In Curas' grammar, noch einmal so viel corresponds to une fois autant, while sechsmal mehr corresponds to six fois davantage, etc.

Numeri distributivi are: cîte unul, einzeln (in Curas' grammar, it is the equivalent of un à un), cite doi, zwei und zwei (in Curas' grammar it is the equivalent for deux à deux), etc.

Nu me ri collectivi are: o păreache, ein Paar (in Curas' grammar it corresponds to une paire), un tuțin, ein Dutzend (in Curas' grammar it has the Fr. equivalent une douzaine), etc.

\subsection{Chapters on verbs}

Chapters XII, XIII , XIV dedicated to the lexical-grammatical class of verbs, contain flexion patterns, firstly of the auxiliary verbs be and have, then of some ver b o r u $\mathrm{m}$ r e g u la ri u m that belong to the four conjugations set out according to the grammatical suffixes $-a,-e a,-e$ and $-i$, and of some ve r b o r u m passivorum, reciprocum and irregularium.

The inflectionary pattern in Molnar's grammar is identical to that of Pepliers' grammar, including the grammatical used terminology:

- indicativus modus (tempus præsens, præteritum imperfectum, præteritum perfectum simplex, præteritum perfectum compositum, præteritum plusquamperfectum I, præteritum plusquamperfectum II, futurum);

- imperativus modus;

- optativusşiconjunctivus modus (tempus præsens, præteritum imperfectum optativi, præteritum imperfectum conjunctivi, præteritum perfectum, praeteritum plusquamperfectum optativi, præteritum plusquamperfectum conjunctivi, futurum);

- infinitivus modus (præsens and præteritum perfectum);

- participium (præsens and futurum);

- supinum;

- gerundia.

Inside the indicative mood, the forms of analytical past perfect made up of the past simple of the verb a fi [to be] and the past participle of the main verb: am fost avut, ai fost avut, au fost avut, etc., with their German equivalents ich hatte gehabt, du hattest gehabt, er hatte gehabt, etc. are recorded under the name of præteritu m plusqua m perfectu m I. Only in case of the auxiliary verb to be, the forms of prateritum plusquamperfectum I are made of the present continuous of the auxiliary verb a fi [to be] and the past participle: eram fost, etc.

The synthetic forms of past perfect are perfectly recorded under the name of præteritum plus qu a m p e f fe ct u m I I: avusăm or avuseasăm, avusăş or avuseasăş, avusă or avuseasă, etc. (with the same German equivalents of: ich hatte gehabt, du hattest gehabt, er hatte gehabt, etc.).

\footnotetext{
${ }^{4}$ In Latin, cardinalis, derived from cardo, -inis, has the meaning of 'main, fundamental, essential'.
} 
In Pepliers' grammar, forms such as javois eu, tu avois eu, il avoit eu (with the German equivalents ich hatte gehabt, du hattest gehabt, er hatte gehabt, etc.) are recorded under the name of p ræt e r it u m plus qua m pe r fectu m I, while those like jeus eu, tu eus eu, ileut eu (with the same equivalents: ich hatte gehabt, du hattest gehabt, er hatte gehabt, etc.) are recorded under the name of p r x t e r i t u m pl u s qu a mperfectum II.

Being included into the subjunctive, the optative is made of op tativus and conjunctiv u s mo$\mathrm{d}$ us. The present forms of optative-conditional-aş avea, tu ai avea, ar avea, etc. (in Pepliers' grammar: j'aurois, tu aurois, il auroit) - are recorded under the name of p ræt e rit u m i m perfect u m op tat ivi, different from præt e r it u m im perfectu m c on ju n ctivi: (de) vream avea, (de) vreai avea, (de) vrea avea, etc. (in French: jeusse, tu eusses, il êेt, etc.). The præteritum i mperfectum optativi has the German equivalent of either Konjunktiv II, Präsens (forms: ich hätte, du hättest, er hätte, etc.), or Konjunktiv II, Futur I (forms: ich würde haben, du würdest haben, erwürde haben, etc.); the p r $x$ t $\mathrm{r}$ r i t u m imperfectum conjunctivi has the German equivalent of Konjunktiv II, Präsens: (wenn) ich hätte, (wenn) du hättest, (wenn) er hätte, etc.

The forms of perfect subjunctive are under the name of p r x t e r i t u m pe r fe c t u m: să fiu avut, săfii avut, să fie avut, etc. (in French: j'aye eu, tu ayes eu, il ait eu, etc.). The German equivalent is Konjunktiv I, Präteritum: ich habe gehabt, du habest gehabt, er habe gehabt, etc.

Forms such as: voi fi avut or voi fi fost avut, vei fi avut or vei fi fost avut, va fi avut or va fi fost avut are considered as præteritum plusquamperfectum optativi (in French, the forms of perfect optative-conditional are used with this name: jaurois eu, tu aurois eu, il auroit eu). The German equivalent of præteritum plusquamperfectum optativi is either Konjunktiv II, Präteritum (forms such as: ich hätte gehabt, du hättest gehabt, er hätte gehabt), or Konjunktiv II, Futur II (forms such as: ich würde gehabt haben, du würdest gehabt haben, er würde gehabt haben).

The perfect optative-conditional (aşfi avut, aifi avut, arfi avut. etc.) is called præteritum plus qua m perfectum conjun ctivi; the forms recorded in Pepliers' grammar under this name are: jeusse $e u$, tu eusses eu, il ềt eu (their German equivalent is Konjunktiv II, Präteritum: ich hätte gehabt, du hättest gehabt, er hätte gehabt, etc.). In the case of some verbs, the forms of perfect conditional are not recorded under the name of præteritum plusquamperfectum conjunctivi but of past perfect conditional (made of the perfect conditional of the verb a fi [to be] + past participle of the main verb): aş fif fost arat, etc.

The future tense (f u t u r u m) of this mood-(de) voi avea, (de) vei avea, (de) va avea, etc. (at Pepliers: j'aurai eu, tu auras eu, il aura eu, etc.) - has the German equivalent of Konjunktiv I, Futur I: (wenn) ich werde haben, (wenn) du wirst haben, (wenn) er wird haben, etc.

The forms shown by Molnar for ger un di a: de a avea, intru a avea, pentru a avea and by Pepliers in French: d'avoir, en ayant, à avoir or pour avoir have the German equivalents, in both grammars: $z u$ haben, im Haben, um zu haben.

Molnar's grammar differs from Micu and Șincai's Elementa, with respect to the conjugation pattern already shown, in the following important aspects:

- the imperative also has a future tense (with forms identical to the present conjunctive: să laud, să lauzi, să laude, etc.);

- the subjunctive mood has four tenses: the present, the past continuous (the present optative-conditional), the perfect, the past perfect (the perfect optative-conditional) versus the seven tenses in Molnar's grammar;

- this mood is only called c on ju n c tiv us (the term optativus is not included in its name) although the present optative is considered the subjunctive past perfect, and the perfect optative is considered past perfect subjunctive;

- the synthetic past perfect called by Molnar præteritum plusquamperfectum II, while in Elementa it is called plusqua merfectum absolutum; 
- in case of the long form of present infinitive is highlighted (for example a laudare); the infinitive has also got a future tense (a fi lăudător);

- according to the Latin flectives, forms such as di and dum (de lăudare, de lăudat -in Latin, ad laudandum or laudandi) and in do (läudind -in Latin, laudando), respectively, are shown by the gerund;

- the participle mood has also got a future tense (of the kind a fi lăudător).

We also noticed that Molnar selects verbs that bear phonetic alternations during their inflection, explicitly drawing the attention to them for each conjugation: a călca (for the alternations $c / c$ : $c a l c / c a l c i$ and $a / a$ : calcă/ călcăm, etc.), a certa (for the alternations e/ea: cert/ceartă and $t / t, t$ cert/cerți etc.); a full pattern of verbs conjugation which receive the flexionary suffix -esc is introduced for the $4^{\text {th }}$ conjugations as well in several moods and tenses.

As Pepliers does in his grammar, Molnar also offers conjugating patterns of passive, reciprocal and irregular verbs. In case of passive verbs, one can see that it is about, in fact, of passive-reflexive (mă văz 'sînt văzut' [I am seen], te vez 'ești văzut' [you are seen], etc.); the German equivalents are verbs in the passive voice (ich werde gesehen, $d u$ wirst gesehen, etc.). The reciprocal verbs, although they receive mă or te before, also receiving the "p a s s i v o r u m form", are not in fact passive, but neutral. Just like in Elementa, the iotacized verbs are included in the irregular category, namely "verba care se termină în $i u$ " [verbs that end in $i u$ ], "dar se pot termina și în $n$ " [but may also end in $n]$ (p. 239).

Chapter XV consists of an inventory, alphabetically ordered, "in which perhaps the best known are ver b a"; more than 1200 words-title are included here. Such an inventory is not found in Elementa; each verb shall also indicate the number of the conjugation to which it belongs and its/their German equivalent / equivalents. Among the foreign studied grammars, Curas' grammar includes a rich inventory in which the verbs are grouped according to their conjugation.

\subsection{Chapter on adverbs}

In the introductory of the adverb class information from Elementa are given in similar formulas: adverbs can be primary or derived; these latter may arise either from adjectives having a verb or an adjective as a regent, or from the nouns; more precisely, from their plural form, by replacing the plurality of the suffix with the -esc suffix, first making an adjective (for example, the noun domn, by replacing the ending $-i$ from the plural suffix domni with the -esc suffix, the adjective domnesc is made) and then an adverb, with the suffix - ește (domneşte).

The classes of adverbs are set out semantically. We also noticed the more detailed classification compared to Elementa, where the following categories are cited and illustrated: I. adverbs of place, II. adverbs of time, III. ordinal adverbs, IV. interrogative adverbs, V. indefinite adverbs, VI. other adverbs of various types. In Nagy's grammar, the class of adverbs are the following:

I. adverbia locum denotantia,

II. adverbia tempus significantia,

III. adverbia numerum denotantia,

IV. adverbia ordinis,

V. adverbia interrogandi,

VI. adverbia quantitatis,

VII. adverbia intendendi \& remittendi,

VIII. adverbia comparandi,

IX. adverbia congregandi,

X. adverbia separandi,

XI. adverbia limitantia,

XII. adverbia eligendi,

XIII. adverbia affirmandi,

XIV. adverbia negandi,

XV. adverbia dubitandi, 
XVI. adverbia hortandi.

For Molnar, the adverbs are divided into nine classes: adverbs of place, adverbs of time, and adverbs of order, quantitative adverbs, qualitative adverbs, adverbs of reduction and magnification, interrogative adverbs, affirmative and negative adverbs, other adverbs.

The first class, the adverbs of place, contains adverbs answering the question unde? [where?], adverbs answering the question incătrăo? [where to?], respectively adverbs that answer the question of de unde? [where from?]. The pattern of Elementa is illustrating this subclass which conforms to Nagy's grammar; there are many examples (represented by simple, compound adverbs and adverbial phrases). There are also some prepositional phrases among the examples (such as în preajma [around] or afară de [outside of]). The second class contains the adverbs of time; and here most examples are found in Micu and Șincai's grammar.

Of the adverbs of orders indicated in Elementa, six are found having the same form/structure (or close ones) at Molnar: de nou, însă, întîiu, pe urmă (at Molnar: pre urmă), de aci (at Molnar: de aici), după aceea (at Molnar: după aceasta); instead of tanda (from Lat. tandem), Molnar points at spre sfirșit (in German endlich, $z u$ Ende). As well, in comparison to Elementa, incîlcit is missing in Molnar, but 24 more other examples are added. Their German equivalents do not occur in Nagy's grammar, but they can be found in Curas. Thus, both in Curas and Molnar we found the following German adverbs of order: nach allen (après tout in French), după toate in Romanian; haufenweise (par troupes in French), cu grămada in Romanian; worauf (après quoi in French), la care in Romanian; von Haus zu Haus (de maison en maison in French), de casă în casă in Romanian; von Wort zu Wort (de mot en mot in French), de cuvînt în cuvînt in Romanian; zugleich (ensemble in French), dinpreună in Romanian; überhaupt (en gros in French), preste tot in Romanian; alles auf ein Mal (tout à la fois in French), totodată in Romanian; gleich (d'abord in French), deloc in Romanian; in Allen (en tout in French), intru toate in Romanian; auf ein Mal (tout à la fois, tout d'un coup in French), deodată in Romanian. In Molnar's German original, the name of this class is Nebenwörter der Ordnung. Adverbia ordinis, while at Curas it is Adverbia ordinis, der Ordnung.

The class of quantitative adverbs is missing in Elementa. This class is set out in Curas' grammar, while the Germn equivalents provided by Molnar for the Romanian are identical with those offered by Curas for French: genug (assés in French), destul; überflüßig (abondamment in French), deprisosit in Romanian; balb und halb (ádemi in French), de jumătate in Romanian; viel (beaucoup in French), mult in Romanian; wenig (peu in French), puțin in Romanian; mehr (d'avantage in French), mai mult in Romanian; vielgrößer (beaucoupplus in French), cu mult mai mare in Romanian; viel weniger (beaucoup moins in French), cu mult mai puțin in Romanian; nicht viel (pas beaucoup in French), nu mult in Romanian; ganz (entièrement in French), intreg in Romanian; aus Mangel (faute de in French), de lipsă in Romanian; allgemach (peu à peu in French), pre incet in Romanian; schier, fast (presque in French), mai in Romanian; ganz und gar nicht (point du tout, rien du tout in French), nicidecit in Romanian; nur (seulement in French), numai in Romanian; genugsam (sufisament in French), din destul in Romanian; zu viel (trop in French), prea mult in Romanian; so viel (tant in French), atîta in Romanian; eben so viel (autant que in French), tocma atita in Romanian; so viel als (autant que in French), atîta cit in Romanian; zwei Mal so viel (deux fois autant in French), de doao ori atîta in Romanian; gänzlich (totalement in French), de tot in Romanian. Two adverbs whose German equivalents are not to be found in Curas' grammar are added: cu rîdicata, with the German equivalent ballenweise, and puțintel, with the equivalent ein bischen. At Molnar, the name of this class of adverbs is Nebenwörter der Menge. Adverbia Quantitatis, while at Curas it is Adverbia Quantitatis, einer Menge oder Mangels.

For comparison, we note that Nagy's grammar refers to the following quantitative adverbs groß (magnum in Latin), lang longe in Latin), ungeheuer (immane, prodigiose in Latin), dick (crasse in Latin), breit (late in Latin), viel (multum in Latin), mehr (plus in Latin), zu sehr (nimis, valde, admodum in Latin), gar (admodum, multum in Latin), sehr viel (valde multum in Latin), zuviel, allzuviel, garzuviel (nimium, nimis multum in Latin), überflüßig (abundanter in Latin), klein (paruum in Latin), kurz (breviter in Latin), dünn (subtiliter in Latin), schmal (arcte in Latin), schlank (graciliter in Latin), wenig (modicum in Latin), sebr 
wenig (valde modicum in Latin), nichts (nihil in Latin), garnichts (plane nibil in Latin), ganz und garnichts (penitus nibil in Latin), nur ein klein wenig (pauxillum tantummodo in Latin).

There is no class of qualitative adverbs in Elementa. For qualitative adverbs, just as in the case of quantitative adverbs, the German equivalents recommended by Molnar are identical to those French qualitative adverbs indicated by Curas. Thus, the German equivalents are: ungern (a contre coeur in French, nebucuros in Romanian); mit Willen (a dessein in French, cu voie in Romanian); ernstlich/ im Ernst (tout de bon in French, dinadins in Romanian); mit Fleiß (à dessein and exprès in French, intr-adins in Romanian); anders (autrement in French, altmintrilea in Romanian); mit Gütel in der Güte (á l'amiable in French, cu bine in Romanian); unbewußt, ohne (mein) Wissen (à l'insu in French, fărăștire in Romanian); inbrünstig (passionement in French, cu rîvnă in Romanian); mit gutem Recht (à bon droit in French, cu direptate bună in Romanian); flüchtig (à la volée in French, flușturat in Romanian); besonders (à part in French, mai vîrtos in Romanian); mit Unrecht/ unrecht (à tort in French, nedirept in Romanian); mündlich (de bouche in French, gură cu gură in Romanian); beständig (constamment in French, statornic in Romanian); schwerlich/ beschwerlich (mal-aisé in French, cu greu in Romanian); gern (volontiers in French, bucuros in Romanian); von neuem (de nouveau in French, de nou in Romanian); mit Recht (de droit in French, cu dirept in Romanian); verkehrt (travers, de travers in French, întors in Romanian); unbesonnen (á l'étourdi and de but en blanc in French, nebăgînd samă in Romanian); unterschiedlich (diversement in French, de multe fealiuri in Romanian); insbesondere (en particulier in French, deosebi in Romanian); noch (encore in French, încă in Romanian).

Some adverbs whose German equivalent are not to be found in Curas' grammar are added: neplăcut (mißfällig in German), de demult (vorzeiten in German), in vreamea cea veche (vor alters in German), in vreamea cea trecută (in der vergangenen Zeit in German), de mijloc (mittelmäßig in German), färă veaste (unvermuthet in German). We also note that in Molnar's German text this class of adverbs is called Nebenwörter der Beschaffenheit. Adverbia Qualitatis, white at Curas it is called Adverbia Qualitatis, der Beschaffenheit.

The next class shown by Molnar is that of the adverbs of reduction and magnification (Nebenwörter der Nachlassung und der Vermehrung. Adverbia remissionis et intenssionis), a class not to be found in Elementa, but which can be found at Curas, as Adverbia remissionis \& intensionis, der Nachlassung und Vermehrung. This time too, in case of most adverbs, the German equivalents indicated by Molnar overlap those indicated by Curas: zusehends (văzind cu ochi in Romanian, à vue d'oeil in French); unendlich (nesfirşit in Romanian, infiniment in French); Schritt vor Schritt (pas de pas in Romanian, pas à pas in French); mittelmäßig (de mijlóc in Romanian, mediocrement in French); zum wenigsten (cît mai puţin in Romanian, au moins in French); nicht so viel (nu atîta in Romanian, pas tant in French); kaum (de-abia in Romanian, à peine in French); nach und nach (pe incept in Romanian, peu à peu in French); so, sohin (aşa in Romanian, là in French); desto beßer (mai bine in Romanian, tant mieux in French).

In the interrogative class, most adverbs are recorded in Elementa: căci, dice (in Elementa, de ce), pentru ce, cît, cum, de cînd, cît de mare, de cîte ori, cît departe, etc. Some adverbs whose German equivalent is identical with those indicated by Curas for the French adverbs are added: pentru ce nu, corresponding to warum nicht (pourquoi pas in French); de unde, correpsonding to woher (d'où in French); cum dară, corresponding to wie denn (comment donc in French); cum aşa, corresponding to wieso (das) (comment cela in French). The original name of the class at Molnar is Fragende Nebenwörter. Adverbia interrogandi, while at Curas: Adverbia interrogandi, des Fragens.

The affirmative and negative class of adverbs, which is missing in Elementa, includes some elements whose German equivalents are to be found as well in Curas' grammar: in adevăr, corresponding to in der Wabrheit (á la vérité in French); cu adevărat, corresponding to gewißlich (assurement and certainement in French); negreșit, corresponding to unfehlbar (infailliblement and sans faute in French); pre credința mea, corresponding to auf meine Treue (ma foi in French); nu am indoială, corresponding to ich habe

\footnotetext{
${ }^{5}$ At Curas: bey meiner Treu.
} 
keinen Zweifel ${ }^{6}$ (sans doute in French); bucuros, corresponding to gerne (volontiers in French); intr-adins, corresponding to im Ernst (sincèrement in French); încă nu, corresponding to noch nicht (encore pas, pas encore in French); nu aşa curînd, corresponding to nicht so bald (pas si tôt in French). This time, too, the name of the class is very close to that suggested by Curas: Nebenwörter der Verleugnung oder Bejahung. Adverbia affirmandi et negandi, instead of Adverbia affirmandi \& negandi, der Bejahung oder Verneinung.

The last class contains other adverbs, as its equivalent in Elementa; both adverbs and adverbial phrases occur in both grammars, e.g.: numai, nimic (as obsolete and popular adverb) 'defel, deloc, nicidecum' (in Elementa, with the form nemica), abia, anevoie, precum, măcar, aşadară, ca, încă, altmintrilea (amintrilea in Elementa), de bună samă (de bună seamă in Elementa), foarte, mai vîrtos, prea, adevărat, mai ales, bine, tocma, lesne, vez-bine (vezi-bine in Elementa), etc. There are also conjunctions (such as deși, findcă) and couplings (măcar că, pentru că).

\subsection{Chapter on conjunctions}

With regard to conjunctions, if in the relevant section of Elementa only a list of conjunctions (and their Latin equivalents) with their usual Romanian usage is presented, in Molnar's grammar more set ups are described within this lexical grammar class instead. The following pattern is taken from Curas' grammar. Firstly, the author takes into consideration the association with the verbal moods, conjunctions that are made by the indicative and the subjunctive or conjunctions which do not require a certain mood are developed; in Curas, "Einige regieren (...) Ind ic a t iv u m oder Conjunctiv u m; einige regieren keinen Modum" (p. 294).

It may be noted that the German equivalents provided by Curas for the French equivalent of the conjunctions coincide largely with Molnar's German grammar; actually the fact that Molnar could have the German conjunctions as his starting point, whom he identified a Romanian equivalent, explains the heterogeneity of the morphological examples offered by him; some are conjunctions, but others belong to other lexical-grammatical classes (most commonly, to the class of adverb).

Thus, if we follow the German equivalents of the conjunctions which are made by the indicative, we can find the following common examples both in Curas and Molnar: nachdem (selon que in French, dupa cum in Romanian); seitdem (depuis que in French, de cind in Romanian); so oft (toutes les fois que in French, de-atîtea ori in Romanian); soviel (als) (autant que in French, atîta cît in Romanian); sobald (als) (dès que or d'abord que in French, cîtva in Romanian); so wie (à ce que in French, precum in Romanian); da (lorsque in French, cînd in Romanian); als (en même temps in French, cînd in Romanian); so lange, wie lange (tant que in French, pînă cînd in Romanian). The Romanian equivalent for damit nicht (ca să nu) is included in the context of the conjunctions that are built with the indicative, while at Curas the equivalent of damit nicht (de crainte que, depeur que in French) is found in the conjunctions that are built with the conjunctive mood.

German common equivalents are also identified in the conjunctions that are made by the subjunctive mood (at Curas, "die Conju n c ti o nes, so den C on ju n ctiv u m regieren", p. 295): im Fall daß (en cas que in French, de s-ar in Romanian); obwohl, obgleich (bien que, quoique, encore que in French, măcar că in Romanian); ehe als (avant que in French, mai nainte de ce s-ar in Romanian); daß (que in French, că in Romanian); bis daß (jusqu'à ce que in French, pînă va in Romanian); wenn gleich (quand même in French, măcar de nu in Romanian).

Although there is not an explicit distinction between the coordinate and subordinate conjunctions, we can see that the restrictions associated with verbal moods are set by the subordinate conjunctions, connecting a subordinate clause by its main clause; coordinating conjunctions between two or more syntactic units of the same significance at the level of the sentence or phrase.

The particularization of conjunctions has lots of similarities with Curas' grammar. The conjunctions not requiring any mood are listed; in Curas: "Folgende Conjunction es regieren keinen Modum":

${ }^{6}$ At Curas: obne Zweifel. 
„1. C op u la tiva, die zusammen fügen, 2. D i s ju n c t iva, die eine Rede aus einander setzen, 3. Adver s at iva, die einen Gegensatz der Rede anzeigen, 4. Ca us a le s, die eine Ursache anzeigen, 5. Exc e p tiva, wann man etwas ausnimmt, 6. C o n clusiva, die einen Schluß machen” (p. 296-297). The same types appear in Molnar's grammar.

Similarly, in the case of the copulative conjunctions, German equivalents are recorded both in Molnar and Curas' grammars; for example, the German auch corresponds to încă in Romanian and aussi in French, nämlich to adecă in Romanian and savoir que in French, nicht allein to nu numai in Romanian and non seulement in French.

The German equivalents common to the Romanian, respectively French disjunctive conjunctions, are: weder einer, noch der andere (nici unul, nici altul in Romanian, ni l'un, ni l'autre in French); entweder, oder (sau, au in Romanian, ou in French); oder aber (sau măcar in Romanian, ou bien in French); es sey (să fie in Romanian, soit in French). Aşadară (derobalben in German); nici (auch nicht in German); și (und in German); ci (aberdoch in German) and altă dată (ein anders Mal in German) are also included in the category of disjunctive conjunctions.

Some of the German adversative conjunctions listed by Curas are also to be found at Molnar: hingegen (dară in Romanian, en échange in French); aber (dară in Romanian, mais in French); doch (și tot in Romanian, mais in French); ungeachtet (măcar că in Romanian, non obstant in French). In Molnar's grammar, the following are also included in the class of adversative conjunctions: pentru că (dieweil in German); fară numai (sondern nur in German); de nu (wenn nicht in German); altmintrilea (ansonsten in German); cît mai mare (je größßer in German); findcă (indem, gleichwie in German); iară (wieder in German); de cumva (allenfalls, wenn, vielleicht in German). If fiindcă and pentru că are considered as adversative, in the causative category, instead, we find the causative adverbial phrase drept aceia, and also ca să nu, cît nu, ca nu cumva, cu atît mai vîrtos.

German equivalents (also given by Curas for French) are identified for the causative conjunctions: damit nicht (ca să nu and ca nu cumva in Romanian, afin de ne in French); um destomehr (cu cît mai vîrtos in Romanian, d'autant plus que in French).

The last two categories are recorded as adverbs of exception (v o c e s e x c e p tivæ) and conclusive adverbs (conclusiva), respectively; the German ausgenommen has afară de and excepté as its Romanian and French equivalents, for außer there is the Romanian afară and French hormis, for über dieses there is preste aceasta in Romanian and outre que in French, for es sey denn there is poate că să in Romanian and $a$ moins que in French. Also, for the conclusives, also corresponds to precum and ainsi, respectively, then endlich to mai pre urmă and enfin, respectively, and dann to atunci and donc, respectively.

In Nagy's grammar the conjunctions are classified, according to one criterion, into twelve syntactic and semantic classes: 1 . copulativæ, 2. causales, 3. continuativæ, 4. comparativæ, 5. disiunctivæ, 6. concessivæ, 7. adversativæ, 8. explanativæ, 9. conditionales, 10. consecutivæ, 11. conclusivæ, 12 . intentionales.

\subsection{Chapter on interjections}

Interjections, "which are given to understand an emotion or a thought" (p. 328), are divided into seven classes. The similarities to Curas' grammar are also included in their names:

1. Zwischenwörter des Bittens und Ermahnens (at Curas: Interjectio, welche bittet und vermahnet);

2. Zwischenwörter, die eine Verwunderung anzeigen (at Curas: Interjectio, welche eine Verwunderung anzeiget);

3. Zwischenwörter des Mitleids (at Curas: Interjectio, welche ein Mitleiden anzeiget);

4. Zwischenwörter, womitman an-und ausruffet (at Curas: Interjectio, womitman einen an-undzurufet);

5. Zwischenwörter der Danksagung (at Curas: Interjectio, womit man Dank saget);

6. Zwischenwörter, wodurch jemand auf die Seite zu gehen angewiesen wird (at Curas: Interjectio, womit man etwas an die Seite treibet); 
7. Zwischenwörter, womit man etwas oder gar still zu schweigen verbiethet (at Curas: Interjectio, womit man etwas verbietet oder still zu schweigen).

Within all these seven classes, words or phrases used in the exclamatory interrogative can have the value of interjections and show surprise, distrust, compassion, contentment, etc.: for example, the pronoun ce having the value of an interjection, meaning 'cum adică?! se poate?!', the adverb afară having the value of an interjection, meaning 'ieși!, pleacă!', the imperative verbs lasă(-mă), taci, etc.

The request and urge interjections class includes three elements: $o$, de (the interjection $o$ followed by the conjunction $d e$ ), $o$, de ar (the $3^{\text {rd }}$ person auxiliary of the conditional is added), both having the German equivalent $o$, wenn; the third interjection is fui, with the German equivalent $p$ fui.

Several interjections "that show surprise" have the same German equivalents as those indicated by Curas for French: großer Gott (corresponding to grand Dieu in French) has mare Dumnezeu as its Romanian equivalent; also, wieso corresponds to comment in French and cum așa in Romanian; was corresponds to quoi in French and ce in Romanian; o, Gott corresponds to o, Dieu in French and ob, Dumnezeule in Romanian; vortreflich corresponds to admirable in French and prea bine in Romanian; ist es möglich? corresponds to est-il possible? in French and iaste cu putință? in Romanian; ach, wie schön! corresponds to que cela est beau! in French and ah, cîtu-i de frumos! in Romanian; es ist nicht möglich corresponds to il n'est pas possible in French and nu-i cu putință in Romanian; in this category we also find ob, Doamne and lasă-mă, corresponding to the German $o$, Herr and lasse mich, which are not to be found in Curas' grammar.

The interjections expressing compassion are $o$, vai; vai; and vai de mine, with the German equivalents $o$, wehe; wehe (which we find at Curas and Nagy as equivalents of French and Latin interjections, respectively).

In the case of interjections expressing a call / an exclamation, they have an equivalent identical or similar to that indicated by Curas: hei, copile (he, du Junge in German), la arme (zum Gewehr in German), spre ajutoriu (zu Hilfe in German).

The two interjections expressing satisfaction (laudă lui Dumnezeu and mulțam lui Dumnezeu) both having German equivalents (gottlob, Gott sey Dank) also occur as French equivalents in Curas' grammar (Dieu merci, graces à Dieu).

It is worth mentioning that in Elementa the chapter on interjections includes a short list of examples (i.e., the interjections o de!, aha!, vai!, ob!, oh, vai!, odată cu inima!, cară-te!, and măi!). In Nagy's grammar the German interjections are classified as it follows: 1. hortantis, 2. iubilantis, 3. dolentis, 4 . optantis, 5. abominantis, 6. minantis, 7. iurantis.

\section{The reception of Molnar's grammar}

Both practical grammar and Romanian handbook, Deutsch-Walachische Sprachlehre is one of the instances of Molnar's efforts to standardize and preserve the language. The success enjoyed by his grammar can be proved not only by its three editions, but also through its subsequent reception. Deutsch-Walachische Sprachlehre served as a pattern for other Romanian grammars; some have taken as such substantial sections of Molnar's work: that of Anton de Marki, Auszug aus der für Normal-und Hauptschulen vorgeschriebenen deutschen Sprachlehre in deutscher und wallachischer Sprache, Cernăuți, 1810 and that of Teoctist Blajevici (Theoktist Blazewicz), Theoretisch-praktische Grammatik der dacoromanischen, das ist: der moldauischen oder wallachischen Sprache [...], Lvov, 1844. Teoctist Blajevici, who will later become Metropolitan of Bukovina and Dalmatia in 1877, published under the name of Teoctist Șoimul (Theoktist Schoimul), two other editions of his grammars: Theoretisch-praktische Taschengrammatik zur leichten und schnellen Erlernung der romanischen (walachischen) Sprache, Wien, 1855, and Kurzgefasste praktische Grammatik der romanischen (walachischen) Sprache: Mit einem praktischen Theile, enthaltend die im Umgange nothwendigsten Wörter, Gespräche, Sprichwörter, Briefe, Lese- und Uebersetzungsübungen, nebst einem Wortverzeichnisse, Zweite Auflage, Wien und Hermannstadt, 1866. 
Another grammar influenced by Deutsch-Walachische Sprachlebre is entitled Walachische Sprachlebre für Deutsche, nebst einem kleinen Walachisch-Deutsch und Deutsch-Walachischen Handwörterbuche, Buda, 1823 ( $2^{\text {nd }}$ edition, 1836), whose author, Andreas Clemens, stated in the preface of the first edition (p. 4) that "Mr. von Müllersheim volume (...) is in the hands of many Romanian fans".

After the newspaper "Wiener Zeitung", in the issue no. 52 of June 28, 1788 (p. 1608), mentions Molnar's grammar amongst the books emerging in Viennese bookstores, the book is reviewed in the prestigious publication „Allgemeine Literatur-Zeitung”, Jena/ Halle, 1789, vol. 2, no. 177, June, p. 606607, a year after its publication; the volume is described here as "the first truly useful Romanian guide [...]" (in the original, "Ungeachtet des häufigen Gebrauchs der Wallachischenn Sprache, auch durch die ganze Moldau, in Siebenbürgen, dem Banat u.s.w. ist dieses die erste recht brauchbare Anleitung dazu" [p. 606]). The second edition of the grammar was presented in "Wiener Allgemeine Literatur-Zeitung" (no. 56 of July 13,1810, p. 895-896). It is worth mentioning that the successful operations carried out by doctor Molnar in Vienna and Bratislava are also included there (in "Wiener Zeitung", no. 78 of September 28,1785 , as well as in no. 20 of March 8, 1788, p. 573), as well as his receiving the title of nobility von Müllersheim (in "Wiener Zeitung", no. 69 of August 25, 1792, p. 2346).

As for the mentions of Molnar's grammar, we note that Gheorghe S,incai, in the preface of the second edition of Elementa lingue daco-romane sive valachice (Buda, 1805), states that "after eight years" since the first edition (in 1780), coauthored by Samuil Micu, "that is, in 1788, this same grammar was revised, added and printed in Vienna, in German and Romanian, by the brilliant Sir Ioan Molnar of Müllersheim" (p. 4). The work is also notified by István Horvát in Rajzolatok a Magyar Nemzet legrégiebb történeteiböl, published by Mátyás Petrózai Trattner in Pesta, 1825.

Testimonies on Molnar's grammar were also written by Bogdan Petriceicu Hasdeu, both in Cuvente den bătrîni, Romanian Academic Society Printing House, Bucharest, 1878-1881, as well as in a letter to Hugo Schuchardt, dated October 27, 1878 (whose original is in the Schuchardt collection of University of Graz Archive), which included observations on the verb aciiu.

Over time, various studies that diachronically approached either the literary language (Werner Bahner, Das Sprach-und Geschichtsbewußtsein in der rumänischen Literatur von 1780 bis 1880, Akademie-Verlag, Berlin, 1967; Jürgen Erfurt, Bildungswesen und Sprachgeschichte: Südostromania, in Gerhard Ernst, MartinDietrich Gleßgen, Christian Schmitt, Wolfgang Schweickhard (eds), Romanische Sprachgeschichte / Histoire linguistique de la Romania. Ein internationales Handbuch zur Geschichte der romanischen Sprachen, 2. Teilband, De Gruyter, Berlin, 2006, p. 1203-1213; Wolfgang Dahmen, Magyarisierungsversuche im Siebenbürgen des 19. Jahrhunderts als Motor für die Sprachnormierung des Rumänischen, in Wolfgang Dahmen, Werner Schlösser (eds), Sexaginta. Festschrift für Johannes Kramer, Helmut Buske Verlag, Hamburg, 2007, p. 97-111), or language contacts (Jon Borcia, Deutsche Sprachelemente im Rumänischen, Doctoral Thesis at the University of Leipzig, 1903), language teaching (Michael Metzeltin and Petrea Lindenbauer, Terminologie und allgemeiner Wortschatz im Spiegel didaktischer Grammatiken. Ein rumänisches Beispiel, in Günter Holtus, Johannes Kramer, Wolfgang Schweickard (eds), Italica et Romanica. Festschrift für Max Pfister zum 65. Geburtstag, Niemeyer, Tübingen, 1997), writing systems (Sebastian Kempgen, Slavic Alphabet Tables, University of Bamberg Press, Bamberg, 2016), medical terminology (V. Bologa, Terminologia medicală românească a doctorului Ioan Piuariu (Molnár von Müllersheim), in "Dacoromania", IV (1), 1924-1926, p. 383-393; V. Bologa, I. Spielmann, Z. Szőkefalvi Nagy, Date noi cu privire la activitatea lui Ioan Piuariu-Molnar, in „Revista Medicală”, no. 15/1970, p. 501-507; Teodora Daniela Sechel, Medical knowledge and the improvement of vernacular languages in the Habsburg Monarchy: A case study from Transylvania (1770-1830), in "Studies in History and Philosophy of Biological and Biomedical Sciences", no. 3, 2012, p. 720-729, etc.) include, as well, references regarding Molnar's grammar.. 


\section{Conclusions}

Sharing the concerns of his times, Molnar in fact joined a goal and some challenges facing the Transylvanian scholars, who self-imposed all these with a high-aimed sense of duty that they could only meet by a joint calling up through a series of efforts and actions. The author of the German-Romanian grammar shares with his contemporary Transylvanian intellectuals both the respect for the authority of reason and the rigor of science, the intellectual curiosity, the polemic spirit, and the relentless diligence. These qualities were added to the size of vocation as in their case: both in the medical profession, which reached a level of recognition and outstanding performance (in 1780 he was called to Vienna by Marshal Peter Gourcy, for the work of cataracts in both eyes; a report by Molnar in 1786 regarding 101 healed cases [Lupass, 1939 , p. 25], etc.), as well as to public events which aimed at upgrading and enlighting both language and society.

\section{Bibliography}

Elementa $=$ Samuil Micu, Gheorghe Șincai, Elementa lingue daco-romane sive valachice, studiu introductiv, traducerea textelor şi note de Mircea Zdrenghea, Editura Dacia, Cluj-Napoca, 1980.

Lupaș, I. (1939). Doctorul Ioan Piuariu-Molnar: viața și opera lui, Imprimeria Națională, București.

Niculescu, Al. (1978). Individualitatea limbii române între limbile romanice, vol. II. Contribuții socioculturale, Editura Științifică şi Enciclopedică, București.

Ursu, N.A. (2002). Contribuții la istoria culturii românești. Studii și note filologice, Editura Cronica, Iași.

Ursu, N.A. (2012). Alte contribuţii la istoria culturii româneşti. Studii și note filologice, Editura Cronica, Iași. 